\title{
PENGARUH MEDIA PEMBELAJARAN BERBASIS AUGMENTED REALITY TERHADAP HASIL BELAJAR SISWA KELAS X PADA KONSEP DINAMIKA PARTIKEL
}

\author{
Herawati Affandi, Iwan Permana Suwarna, Erina Hertanti \\ Universitas Negeri Jakarta \\ Email: iwan.permana.suwarna@gmail.com
}

\begin{abstract}
This research aims to determine the effect of learning media based on Augmented Reality to learning outcome of students $10^{\text {th }}$ grade on the concept particle dynamics. This research was done in $10^{\text {th }}$ grade science class: 2 and 4 in SMA 67 Jakarta. The research was done in October-November 2013. The research method is a quasi experimental with a noneqiuvalent control group design and the sampling technique is purposive. Instruments of the research are test (multiple choices) and non test(questionnaire). Data were analyzed quantitatively using the $t$ test, questionare analyzed qualitatively. The conclution : there is the influence of augmented reality-based instructional media on learning outcome of students grade 10th on the concept particle dynamics. Average learning outcome experiment group is higher than control group. The experimental group superior on cognitive level $\left(\mathrm{C}_{1}-\mathrm{C}_{4}\right)$. Carrying capacity of the media Augmented Reality on the learning process had teacher done is excellent category $(83.24 \%)$.
\end{abstract}

Keywords: concept of particle dynamic, ARToolkit, augmented reality, physics learning outcome, physics teaching media

\begin{abstract}
Abstrak: Penelitian ini bertujuan untuk mengetahui pengaruh penggunaan media pembelajaran berbasis Augmented Reality terhadap hasil belajar siswa kelas X pada konsep dinamika partikel. Penelitian dilakukan di kelas X: IPA-2,dan IPA-4 SMA Negeri 67 Jakarta. Penelitian ini dikerjakan selama OktoberNovember tahun 2013. Metode penelitian yang digunakan kuasi eksperimen dengan desain non eqiuvalent control group. Teknik pengambilan sampel purposive. Instrumen yang digunakan berupa soal pilihan ganda dan non tes (angket). Data tes dianalisis secara kuantitatif menggunakan uji t, data non tes secara kualitatif. Kesimpulan dari penelitian ini: media pembelajaran berbasis Augmented Reality berpengaruh terhadap hasil belajar siswa kelas X pada konsep dinamika partikel. Rata-rata hasil belajar siswa kelas eksperimen lebih tinggi dibandingkan kelas kontrol. Siswa kelas eksperimen unggul pada jenjang kognitif $\left(\mathrm{C}_{1}-\mathrm{C}_{4}\right)$. Daya dukung media Augmented Reality pada proses pembelajaran ada pada kategori baik sekali $(83,24 \%)$.
\end{abstract}

Kata Kunci: konsep dinamika partikel, ARToolkit, augmented reality, hasil belajar Fisika, media pembelajaran Fisika

\section{Pendahuluan}

Mata pelajaran Fisika pada umumnya dikenal sebagai mata pelajaran yang ditakuti dan tidak disukai para siswa. Kecenderungan ini biasanya berawal dari pengalaman belajar siswa yang menemukan kenyataan bahwa pelajaran Fisika adalah pelajaran berat dan serius. Pelajaran Fisika erat hubungannya dengan pemahaman konsep dan penyelesaian soal-soal yang rumit. Untuk itu diperlukan media pembelajaran yang tepat dalam proses belajar mengajar Fisika, terutama pada konsep yang tergolong rumit dan merupakan dasar bagi siswa yang akan mempelajari konsep Fisika pada materi dan kompetensi dasar selanjutnya.

Konsep-konsep Fisika akan lebih mudah dipahami jika materi tersebut divisualisasikan menjadi nyata, baik berupa visualisasi statis maupun visualisasi dinamis. Melalui visualisasi materi menjadi lebih menarik sehingga menambah motivasi untuk mempelajari Fisika. Namun, ada beberapa materi yang tergolong sulit untuk divisualisasikan sehingga kurang memotivasi siswa. Misalnya, pada konsep dinamika partikel kelas X. Salah satu materi yang 
dibahas dalam konsep ini adalah aplikasi hukum Newton. Pada materi ini dijelaskan arah-arah gaya sebuah benda yang diletakkan pada bidang datar, bidang miring, benda yang dihubungkan dengan tali, dan benda yang dihubungkan dengan katrol.

Selama ini media yang digunakan untuk memvisualisasikan materi dinamika partikel hanya papan tulis dan spidol. Guru menjelaskan materi secara lisan dan benda-benda yang berkaitan dengan materi tersebut digambar menggunakan spidol di papan tulis, kemudian diberikan anak panah untuk menunjukkan araharah gayanya. Dengan media tersebut siswa akan menjadi paham, tetapi setelah beberapa lama siswa akan merasa bosan karena gambar terlihat sederhana dan hanya terlihat satu dimensi. Gambar tersebut kurang memotivasi siswa dalam belajar, sehingga proses pembelajaran Fisika menjadi kurang menarik yang membuat siswa merasa jenuh dan merasa kesulitan untuk menyelesaikan soal dinamika partikel yang bersifat matematis dan memerlukan kemampuan analisis. Hal ini mengakibatkan hasil belajar siswa rendah.

Berdasarkan hal di atas, diperlukan media pembelajaran yang menarik, dan tidak membosankan. Media yang bisa menimbulkan rasa ketertarikan siswa untuk terfokus pada pembelajaran dan dapat memperjelas materi yang disampaikan. Siswa tidak hanya paham, tetapi juga semangat dalam mempelajari Fisika, khususnya pada konsep dinamika partikel. Banyak media pembelajaran berbasis multimedia akhir-akhir ini, tetapi hanya sebatas penggunaan pointer, seperti mouse ataupun keyboard saja. Kurang memberikan derajat kebebasan sudut pandang. Sejalan dengan perkembangan teknologi, muncullah teknologi Augmented Reality (disingkat AR), diterjemahkan bebas menjadi realitas tertambah. Secara umum, Augmented Reality adalah penggabungan antara objek virtual dan objek nyata.

Augmented Reality (AR) ini merupakan teknologi yang menggabungkan benda maya ke dalam sebuah lingkungan nyata tiga dimensi dan menampilkannya dalam waktu nyata, sehingga gambar tersebut terkesan hidup dan seolah nyata berada dihadapan kita. Augmented Reality memiliki banyak peluang untuk terus dikembangkan, tidak ketinggalan dalam bidang pendidikan. Di Indonesia sendiri Augmented Reality mulai dikenal enam tahun terakhir ini. Sama seperti di negara-negara lain, beberapa penelitian dan pengembangan dalam bidang pendidikan juga telah dilakukan. Dari beberapa hasil penelitian dalam bidang pendidikan, Augmented Reality menunjukkan hasil yang positif dan membuktikan bahwa Augmented Reality dapat diterapkan dengan baik dalam dunia pendidikan, khususnya sebagai sebuah media pembelajaran.

Dalam bidang pendidikan, teknologi Augmented Reality dapat digunakan sebagai pelengkap media pembelajaran yang sudah ada saat ini. Teknologi Augmented Reality dapat mengatasi keterbatasan ruang, waktu dan daya indra seperti alat peraga yang terlalu besar dan tidak mungkin ditampilkan di dalam kelas dapat ditampilkan dengan teknologi ini. Dengan teknologi ini alat peraga dikemas dalam bentuk gambar tiga dimensi yang dapat bergerak. Kemudian gambar tiga dimensi tersebut diexport ke dalam bentuk marker. Marker adalah gambar berpola yang berbentuk persegi dengan bingkai berwarna hitam. Setelah itu marker diarahkan menuju webcam dan webcam akan mendeteksi marker tersebut sehingga akan muncul animasi tiga dimensi di atas marker.

Teknologi ini sangat tepat digunakan dalam pembelajaran Fisika khususnya pada konsep dinamika partikel. Dengan teknologi ini konsep dinamika partikel akan ditampilkan dalam bentuk gambar tiga dimensi yang dapat bergerak, sehingga gambar terkesan hidup dan tidak membosankan. Animasi tiga dimensi dalam Augmented Reality ini dapat membantu siswa dalam memahami materi yang diberikan oleh pendidik, seperti dalam memahami arah-arah gaya dalam hukum Newton. Arah-arah gaya pada 
bidang datar, bidang miring, benda yang dihubungkan pada tali, dan benda yang dihubungkan pada katrol akan lebih jelas jika ditampilkan dengan teknologi Augmented Reality karena arah-arah gaya tersebut dibuat bergerak. Selain itu benda-benda seperti balok dan katrol terlihat seperti sungguhan dan seolah nyata ada di hadapan kita.

Dengan bantuan teknologi augmented reality, pembelajaran dapat dibuat menjadi lebih menarik. Augmented Reality dapat berperan dalam menumbuhkan minat belajar siswa. Siswa dapat secara langsung mengamati objek tiga dimensi dan melakukan pembelajaran yang lebih efektif dibandingkan dengan gambar satu atau dua dimensi. Objek tiga dimensi yang dihasilkan dari Augmented Reality dapat meningkatkan kemampuan analisis siswa, sehingga memudahkan siswa untuk menyelesaikan soal dinamika partikel yang bersifat matematis. Selain itu, media ini juga dapat memotivasi dan memunculkan rasa ingin tahu siswa karena sistem pembelajaran Augmented Reality berbeda dengan pembelajaran yang sudah ada. Dengan hal tersebut diharapkan hasil belajar Fisika siswa semakin baik.

Berdasarkan uraian di atas, rumusan masalah dalam penelitian ini adalah "Bagaimana pengaruh media pembelajaran berbasis Augmented Reality terhadap hasil belajar siswa kelas X pada konsep dinamika partikel?”. Penelitian ini dilakukan dengan tujuan yang ingin dicapai, yaitu untuk mengetahui pengaruh media pembelajaran berbasis Augmented Reality terhadap peningkatan hasil belajar siswa kelas X pada konsep dinamika partikel.

Hasil penelitian ini diharapkan dapat memberikan sejumlah manfaat diantaranya: (1) memperjelas materi dinamika partikel karena arah-arah gaya dibuat bergerak, berwarna, dan tiga dimensi, (2) membantu guru dalam mengatasi keterbatasan alat, yaitu dapat menampilkan alat peraga yang tidak mungkin ditampilkan di dalam kelas, (3) menumbuhkan motivasi dan minat belajar siswa untuk mempelajari Fisika khususnya materi dinamika partikel.

\section{Landasan Teori}

\section{Pengertian Augmented Reality}

Augmented Reality (AR) dalam bahasa Indonesia disebut realitas tertambah. Teknologi Augmented Reality merupakan salah satu trobosan yang digunakan pada akhir-akhir ini di dibidang interaksi. Penggunaan teknologi ini akan sangat membantu dalam menyampaikan suatu informasi kepada pengguna. Menurut Kurniawan, Augmented Reality merupakan teknologi interaksi yang menggabungkan antara dunia nyata (real world) dan dunia maya (virtual world). ${ }^{1}$

Menurut definisi Ronald Azuma, ada tiga prinsip dari augmented reality, yaitu (1) Augmented Reality merupakan penggabungan dunia nyata dan virtual, (2) berjalan secara interaktif dalam waktu nyata (real time), dan (3) terdapat integrasi antar benda dalam tiga dimensi, yaitu benda maya terintegrasi dalam dunia nyata. ${ }^{2}$

\section{Jenis-Jenis Augmented Reality}

Berdasarkan metode penggunaannya Augmented Reality (AR) terbagi menjadi dua jenis, yaitu:

1) Marker Augmented Reality (Marker Based Tracking)

Marker Augmented Reality atau Marker Based Tracking merupakan sebuah metode yang memanfaatkan marker. Marker biasanya merupakan ilustrasi hitam dan putih persegi dengan batas hitam tebal dan latar belakang putih (contoh marker dapat dilihat pada gambar $1)$.

\footnotetext{
${ }^{1}$ Kurniawan Teguh Martono, “Augmented Reality Sebagai Metafora Baru dalam Teknologi Interaksi Manusia dan Komputer”, Jurnal Sistem Komputer, vol.1, 2011, h. 60.

${ }^{2}$ Ronald Azuma T., A Survey of Augmented Reality, (Hughes Research Laboratories: Malibu,1997), p. 355-385.
} 


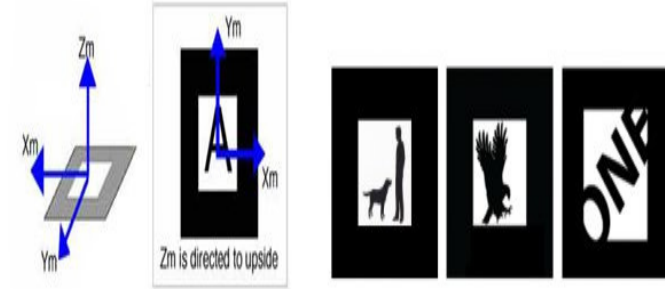

Gambar 1. Marker Sumber: KompasTekno

2) Markerless Augmented Reality

Salah satu metode Augmented Reality yang saat ini sedang berkembang adalah metode "Markerless Augmented Reality", dengan metode ini pengguna tidak perlu lagi menggunakan sebuah marker untuk menampilkan elemenelemen digital. Seperti yang saat ini dikembangkan oleh perusahaan Augmented Reality terbesar di dunia Total Immersion, mereka telah membuat berbagai macam teknik Markerless Tracking sebagai teknologi andalan mereka, seperti:

a) Face Tracking

Dengan menggunakan alogaritma yang mereka kembangkan, komputer dapat mengenali wajah manusia secara umum dengan cara mengenali posisi mata, hidung, dan mulut manusia, kemudian akan mengabaikan objekobjek lain di sekitarnya seperti pohon, rumah, dan benda-benda lainnya. Teknik ini pernah digunakan di Indonesia pada Pekan Raya Jakarta 2010 dan Toy Story 3 Event. Contoh markerless face tracking dapat dilihat pada gambar $2 \mathrm{di}$ bawah ini.

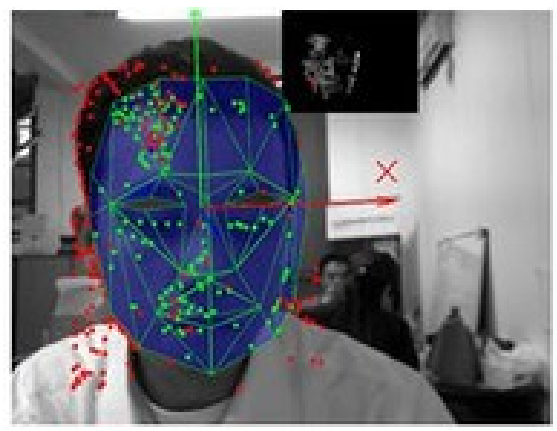

Gambar 2. Markerless AR pada FaceTracking Sumber: KompasTekno

\section{b) 3D Object Tracking}

Berbeda dengan Face Tracking yang hanya mengenali wajah manusia secara umum, teknik
$3 D$ Object Tracking dapat mengenali semua bentuk benda yang ada disekitar, seperti mobil, meja, televisi, dan lain-lain.

c) Motion Tracking

Pada teknik ini komputer dapat menangkap gerakan, Motion Tracking telah mulai digunakan secara ekstensif untuk memproduksi film-film yang mencoba menyimulasikan gerakan. Contohnya pada film Avatar, di mana James Cameron menggunakan teknik ini untuk membuat film tersebut dan menggunakannya secara realtime.

\section{Media Pembelajaran Berbasis Augment- ed Reality}

Media pembelajaran ini merupakan perkembangan teknologi dari hasil gabungan teknologi cetak dan komputer. Salah satu bentuk akhir dari media pembelajaran yang akan dibuat adalah dalam bentuk kartu. Kartu tersebut merupakan print out dari marker yang telah dibuat. Setiap marker akan menampilkan model tiga dimensi yang berbeda. Model tiga dimensi tersebut dapat muncul dengan bantuan kamera webcam pada komputer ketika marker diarahkan pada kamera, sehingga nantinya model-model tiga dimensi (objek maya) dapat ditampilkan dalam dunia nyata pada waktu real time, dan ini merupakan prinsip dasar dari teknologi AR itu sendiri.

Tahap pembuatan media pembelajaran berbasis Augmented Reality adalah sebagai berikut.

1) Perancangan media : Merancang animasi apa saja yang akan dibuat.

2) Pembuatan model 3 dimensi : Model tiga dimensi akan dibuat menggunakan program 3 DS max.

3) Pembuatan marker : Sesuai dengan namanya marker digunakan sebagai medium untuk membantu memunculkan objek 3 dimensi (yang telah dibuat sebelumnya) pada aplikasi augmented reality. Satu marker untuk satu objek 3 dimensi. 
4) Tahap packaging / scripting ARToolKit : Ketiga komponen di atas yaitu model 3 dimensi, market, dan terakhir kartu telah dibuat. Selanjutnya digabungkan ketiga komponen tersebut dan mengujinya.

\section{Metode Penelitian}

Penelitian ini dilaksanakan di SMA Negeri 67 Jakarta Timur. Penelitian berlangsung pada semester ganjil tahun pelajaran 2013/2014. Pengambilan data dilakukan pada bulan Oktober-November. Metode penelitian ini adalah quasi experimental (eksperimen semu). Desain eksperimennya non eqiuvalent control group design. Populasi umum dalam penelitian ini adalah seluruh siswa di SMA Negeri 67 Jakarta dan yang menjadi populasi target adalah siswa kelas X di SMA Negeri 67 Jakarta yang terdiri dari kelas X-IPA-1 sampai dengan X-IPA-4. Penentuan sampel penelitian dipilih secara cermat agar kedua kelas ini memiliki homogenitas yang relatif sama. Sampel adalah bagian dari jumlah dan karakteristik yang dimiliki oleh populasi tersebut. Sampel yang digunakan dalam penelitian ini adalah siswa kelas X-IPA-2 sebagai kelas eksperimen, sedangkan kelas kontrolnya kelas X-IPA-4. Dalam penelitian ini pengambilan sampel dilakukan dengan teknik non probabilitas purposive sampling. Menurut Juliansyah Noor, Purposive sampling merupakan teknik penentuan sampel dengan pertimbangan khusus sehingga layak dijadikan sampel. ${ }^{3}$ Pertimbangan tersebut adalah siswa yang memiliki kemampuan yang sama.

Sebelum perlakuan (treatment) kedua kelas baik eskperimen maupun kontrol di beri pretest. Setelah pretest diberi perlakuan (treatment) yaitu media pembelajaran berbasis augmented reality, kelas kontrol tidak diberikan perlakuan yang sama dengan kelas eksperimen, tetapi perlakuan yang standar yang berlaku di dalam sekolah

${ }^{3} J u l i a n s y a h$ Noor, Metodologi Penelitian: Skripsi, Tesis, Disertasi, \& Karya Ilmiah, (Jakarta: Kencana Prenada Media Group, 2012), h. 234. tersebut. Setelah itu kedua kelas diberi posttest. Instrumen yang digunakan dalam penelitian adalah teknik tes (tes hasil belajar berupa tes objektif pilihan ganda) dan non tes (angket persepsi siswa).

\section{Hasil dan Pembahasan Hasil Pretest dan Posttest}

Hasil pretest dan posttest kelas eksperimen dan kontrol dari 36 siswa adalah sebagai berikut:

Tabel .1 Rekapitulasi Data Pretest dan Posttest Kelas Eksperimen dan Kelas Kontrol

\begin{tabular}{lcccc}
\hline Pemusatan & \multicolumn{2}{c}{ Pretest } & \multicolumn{2}{c}{ Posttest } \\
\cline { 2 - 5 } $\begin{array}{c}\text { dan } \\
\text { Penyebaran } \\
\quad \text { Data }\end{array}$ & $\begin{array}{c}\text { Kelas } \\
\text { Eksperimen }\end{array}$ & $\begin{array}{c}\text { Kelas } \\
\text { Kontrol }\end{array}$ & $\begin{array}{c}\text { Kelas } \\
\text { Eksperimen }\end{array}$ & $\begin{array}{c}\text { Kelas } \\
\text { Kontrol }\end{array}$ \\
$\begin{array}{l}\text { Nilai } \\
\text { Terendah }\end{array}$ & 20,00 & 15,00 & 55,00 & 35,00 \\
$\begin{array}{l}\text { Nilai } \\
\text { Tertinggi }\end{array}$ & 60,00 & 65,00 & 100,00 & 90,00 \\
Rata-rata & 36,61 & 39,94 & 78,94 & 71,72 \\
Median & 35,41 & 41,50 & 82,50 & 72,00 \\
Modus & 35,41 & 47,70 & 81,30 & 86,32 \\
Standar & 10,71 & 13,28 & 13,31 & 14,16 \\
Deviasi & & & & \\
\hline
\end{tabular}

Berdasarkan tabel diatas pretest kelas eksperimen memiliki nilai rata-rata (mean) lebih rendah dibandingkan kelas kontrol dan pada saat posttest kelas eksperimen memiliki nilai rata-rata (mean) lebih tinggi dibandingkan kelas kontrol. Kelas eksperimen maupun kelas kontrol mengalami peningkatan nilai rata-rata (mean) hasil belajar.

Analisis data pretest kelas eksperimen maupun kelas kontrol berdasarkan jenjang kognitif ditunjukkan pada diagram berikut:

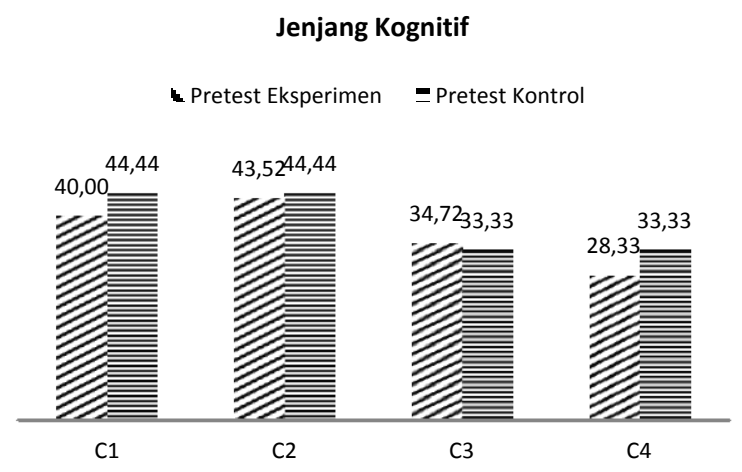

Gambar 3 Diagram Pretest Berdasarkan Jenjang Kognitif 
Gambar 3. menunjukkan persentase pretest kelas eksperimen dan kelas kontrol berdasarkan jenjang kognitif. Persentase jenjang kognitif antara kelas eksperimen dan kelas kontrol pada hasil pretest ini tidak berbeda jauh.

Adapun analisis posttest kelas eksperimen maupun kelas kontrol berdasarkan jenjang kognitif ditunjukkan pada diagram berikut:

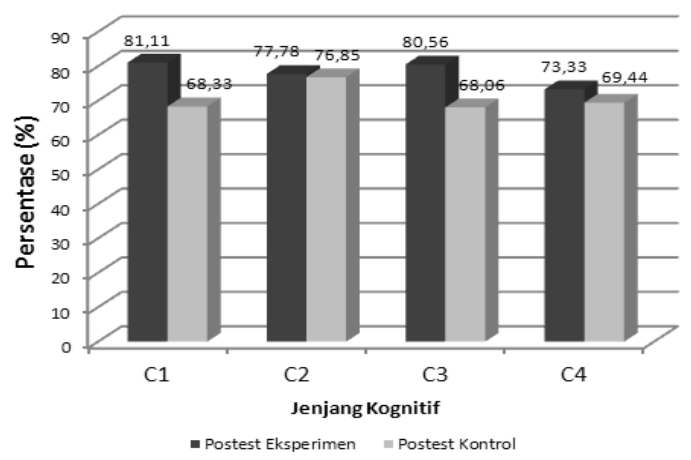

Gambar 4. Diagram Posttest Berdasarkan Jenjang Kognitif

Gambar 4 menunjukkan persentase posttest kelas eksperimen dan kelas kontrol berdasarkan jenjang kognitif. Diagram di atas menunjukkan bahwa persentase setiap jenjang kognitif kelas eksperimen lebih tinggi dari pada kelas kontrol. Perbedaan persentase tersebut tidak jauh berbeda, tetapi perbedaan persentase yang paling terlihat adalah pada jenjang kognitif $\mathrm{C}_{1}$ sebesar $12,78 \%$ dan $\mathrm{C}_{3}$ sebesar $12,50 \%$.

\section{Hasil uji prasyarat}

Pengujian normalitas terhadap hasil pretest, posttest kelas X-IPA-2 dan hasil pretest, posttest kelas X-IPA-4 sebagai kelas kontrol. Untuk menguji normalitas kedua data digunakan rumus Uji Kai Kuadrat (chi square). Berikut ini adalah hasil yang diperoleh dari perhitungan tersebut:

Tabel 2. Hasil Perhitungan Uji Normalitas Kai Kuadrat Pretest dan Posttest Kelas Eksperimen dan Kelas Kontrol

\begin{tabular}{ccccc}
\hline Statistik & \multicolumn{2}{c}{ Pretest } & \multicolumn{2}{c}{ Posttest } \\
\hline & $\begin{array}{c}\text { Kelas } \\
\text { Eksperimen }\end{array}$ & $\begin{array}{c}\text { Kelas } \\
\text { Kontrol }\end{array}$ & $\begin{array}{c}\text { Kelas } \\
\text { Eksperimen }\end{array}$ & $\begin{array}{c}\text { Kelas } \\
\text { Kontrol }\end{array}$ \\
\hline $\begin{array}{c}\text { Nilai } \\
\boldsymbol{X}_{\text {hitung }}\end{array}$ & 8,08 & 4,08 & 5,76 & 4,76 \\
\hline
\end{tabular}

\begin{tabular}{ccccc}
\hline Nilai $\boldsymbol{X}_{\text {tabel }}^{\mathbf{2}}$ & \multicolumn{4}{c}{11,07} \\
Keputusan & $\begin{array}{c}\text { Data } \\
\text { terdistribusi } \\
\text { normal }\end{array}$ & $\begin{array}{c}\text { Data } \\
\text { terdistrib- } \\
\text { usi normal }\end{array}$ & $\begin{array}{c}\text { Data } \\
\text { terdistribusi } \\
\text { normal }\end{array}$ & $\begin{array}{c}\text { Data } \\
\text { terdistri- } \\
\text { busi } \\
\text { normal }\end{array}$ \\
\end{tabular}

Sama halnya seperti uji normalitas, pengujian homogenitas juga dilakukan pada kedua data pretest dan posttest. Berikut adalah hasil yang diperoleh dari uji homogenitas:

Tabel 3. Hasil Perhitungan Uji Homogenitas

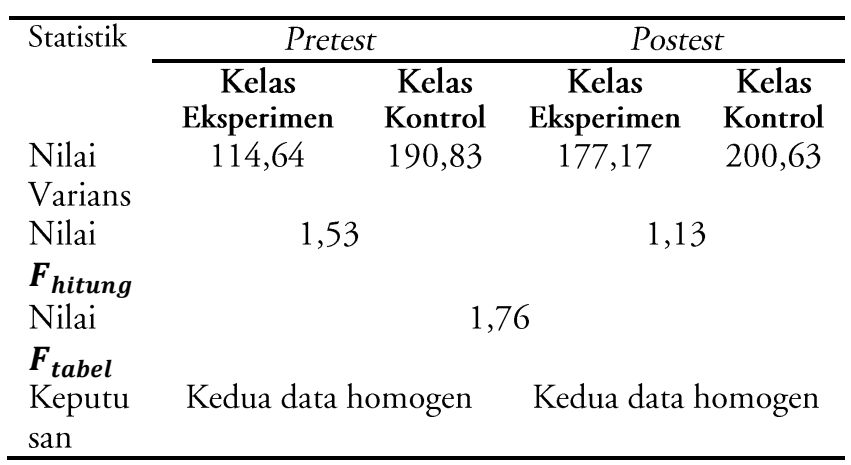

Berdasarkan uji prasyarat analisis statistik, diperoleh bahwa kedua data terdistribusi normal dan homogen. Oleh karena itu, pengujian hipotesis dapat dilakukan dengan menggunakan analisis tes statistik parametik. Perhitungan untuk menentukan nilai $t_{\text {hitung }}$ disajikan pada lampiran. Berikut adalah tabel pengujian hipotesis penelitian data pretest dan posttest.

Tabel 4. Hasil Perhitungan Uji Hipotesis

\begin{tabular}{cll}
\hline Statistik & Pretest & Posttest \\
\hline $\boldsymbol{t}_{\text {hitung }}$ & 1,15 & 2,21 \\
$\boldsymbol{t}_{\text {tabel }}$ & 2,00 & \\
Keputusan & $\mathrm{H}_{\mathrm{a}}$ ditolak & $\mathrm{H}_{\mathrm{a}}$ diterima \\
\hline
\end{tabular}

Hasil uji statistik $\mathrm{H}_{a}$ diterima pada pengujian hipotesis tersebut, dapat disimpulkan bahwa penelitian ini dapat menguji kebenaran hipotesis yaitu terdapat pengaruh media pembelajaran berbasis Augmented Reality terhadap hasil belajar siswa kelas $\mathrm{X}$ pada konsep dinamika partikel.

\section{Hasil Analisis Data Angket}

Hasil data angket yang telah diperoleh selanjutnya diolah secara kualitatif. 82,95 \% siswa merasakan manfaat positif dari media 
pembelajaran berbasis Augmented Reality pada konsep dinamika partikel. Kemudian 83,00\% siswa memberikan respon positif bahwa contoh penerapan hukum Newton dan arah-arah gaya pada berbagai bidang lebih menyenangkan dan lebih mudah dipahami jika disampaikan menggunakan media augmented reality. Persentase mengenai tampilan animasi adalah sebesar 84,86 \% siswa menyatakan bahwa animasi menarik, tidak membosankan, dan keterangan-keterangan arah-arah gaya pada objek dapat membantu penjelasan materi. Selanjutnya sebesar $82,14 \%$ siswa menyatakan bahwa penerapan media Augmented Reality ini memberikan pengalaman baru yang menarik dan menginginkan media ini juga diterapkan pada materi lain pada konsep Fisika.

Berdasarkan hal di atas dapat terlihat bahwa secara keseluruhan penerapan media pembelajaran berbasis Augmented Reality dalam pembelajaran Fisika konsep dinamika partikel memperoleh hasil pada kategori baik sekali. Artinya, penerapan media pembelajaran berbasis Augmented Reality dapat diterima oleh para siswa.

\section{Pembahasan}

Berdasarkan tes tertulis di awal pembelajaran, yang selanjutnya dilakukan uji kesamaan dua rata-rata pretest diketahui bahwa hasil belajar Fisika siswa kedua kelas penelitian pada konsep dinamika partikel menunjukkan tidak adanya perbedaan yang signifikan. Hal ini menunjukkan bahwa siswa pada kelas eksperimen dan kontrol memiliki hasil belajar Fisika awal yang sama pada konsep dinamika partikel. Hasil uji hipotesis menunjukkan bahwa media pembelajaran berbasis Augmented Reality berpengaruh terhadap hasil belajar Fisika siwa pada konsep dinamika partikel. Hal ini terlihat dari perbedaan nilai rata-rata (mean) yang signifikan antara kelas eksperimen dan kelas kontrol pada konsep dinamika partikel. Nilai rata-rata (mean) siswa kelas eksperimen yang menggunakan media pembelajaran berbasis Augmented Reality lebih tinggi dibandingkan siswa kelas kontrol yang tidak menggunakan media pembelajaran berbasis Augmented Reality, terdapat selisih sebesar 7,22. Hasil penelitian ini sama dengan hasil penelitian Nugraha yang menyimpulkan bahwa terdapat perbedaan hasil belajar yang signifikan terhadap hasil belajar siswa antara sebelum dengan sesudah penggunaan media pembelajaran berbasis Augmented Reality pada konsep elektronika dasar. ${ }^{4}$

Hal di atas dapat terjadi karena selama proses pembelajaran dengan menggunakan media pembelajaran berbasis Augmented Reality siswa merasa tertarik dan termotivasi untuk belajar, sehingga hasil belajar siswa dapat meningkat. Hal ini senada dengan pendapat Sadirman yang mengatakan bahwa dalam kegiatan belajar, motivasi dapat dikatakan sebagai keseluruhan daya penggerak di dalam diri siswa yang menimbulkan kegiatan belajar, yang menjamin kelangsungan dari kegiatan belajar dan yang memberikan arah dalam kegiatan belajar, sehingga tujuan yang dikehendaki subjek belajar itu dapat tercapai. Hasil belajar akan optimal kalau ada motivasi yang tepat.

Media pembelajaran Augmented Reality ini adalah media yang baru untuk siswa, media ini menggabungkan benda maya ke dalam sebuah lingkungan nyata tiga dimensi dan menampilkannya dalam waktu nyata, sehingga gambar tersebut terkesan hidup dan seolah nyata berada di hadapan kita. Media pembelajaran ini menggunakan lima buah marker yang dibuat melalui program photoshop dan enam program ARToolkit yang masing-masing berisi animasi yang berbeda. ARToolkit adalah software library

\footnotetext{
${ }^{4}$ Erwin Nugraha, "Upaya Meningkatkan Hasil Belajar Siswa pada Materi Elektronika Dasar Menggunakan Media Pembelajaran Berbasis Augmented Reality", Skripsi pada Jurusan Teknik Elektro Fakultas Pendidikan Teknologi dan Kejuruan Universitas Pendidikan Indonesia, (Bandung: UPI, 2013), h. 168 .

${ }^{5}$ Sardiman, Interaksi dan Motivasi Belajar Mengajar, ( Jakarta: Rajawali Pers, 2011), h. 230.
} 
untuk membangun Augmented Reality (Andriyadi). ${ }^{6}$ Program ARToolkit yang pertama berisi animasi yang merupakan contoh penerapan hukum I Newton (mobil yang melaju kemudian direm mendadak), hukum II Newton (mendorong meja yang masanya berbeda), dan hukum III Newton (seorang anak yang bermain skateboard kemudian menabrak dinding).

Kemudian program ARToolkit yang kedua berisi animasi arah-arah gaya pada benda diam yang diletakkan pada berbagai bidang, yaitu bidang datar, bidang miring, dan vertikal. Selanjutnya program ARToolkit yang ketiga berisi animasi benda bergerak pada pada bidang datar yang ditarik dengan tali yang sejajar dengan bidang dan ditarik dengan tali yang membentuk sudut. Pada program ARToolkit yang keempat berisi animasi benda bergerak pada bidang miring. Pada program ARToolkit yang kelima berisi animasi lift yang bergerak naik, turun, dan jatuh bebas. Pada animasi lift ini dapat dilihat proses pergerakan lift seperti sungguhan. Kemudian program ARToolkit yang terakhir berisi animasi benda bergerak yang dihubungkan dengan katrol. Katrol dibuat seperti sungguhan dengan warna menarik yang dapat bergerak dan disertai arah-arah gaya.

Animasi-animasi pada keenam program ARToolkit di atas terbukti dapat membantu meningkatkan keempat jenjang kognitif. Hal ini dapat dilihat dari perolehan persentase jenjang kognitif pada kelas eksperimen yang menunjukkan peningkatan pada keempat aspek kognitif yang lebih tinggi dibandingkan kelas kontrol. Jika ditinjau dari segi peningkatan, kelas eksperimen unggul dalam meningkatkan kemampuan mengingat $\left(\mathrm{C}_{1}\right)$ sebesar $41,11 \%$, memahami $\left(\mathrm{C}_{2}\right)$ sebesar 34,26\%, menerapkan $\left(\mathrm{C}_{3}\right)$ sebesar $45,83 \%$ dan menganalisis $\left(\mathrm{C}_{4}\right)$ sebesar 45,00\%. Sementara kelas kontrol dapat meningkatkan kemampuan mengingat $\left(\mathrm{C}_{1}\right)$ sebesar 23,89\%, memahami $\left(\mathrm{C}_{2}\right)$ sebesar

\footnotetext{
${ }^{6}$ Anggi Andriyadi, Augmented Reality With ARToolkit, (Bandar Lampung: ARTeam, 2011), h. 65.
}

32,41\%, menerapkan $\left(\mathrm{C}_{3}\right)$ sebesar 34,72\% dan menganalisis $\left(\mathrm{C}_{4}\right)$ sebesar 36,11\%.

Berdasarkan data di atas, dapat dikatakan bahwa media ini memudahkan siswa untuk memahami materi dinamika partikel. Hal ini didukung oleh hasil angket siswa, yaitu sebesar $83,00 \%$ siswa memberikan respon positif bahwa contoh penerapan hukum Newton dan arah-arah gaya pada berbagai bidang lebih menyenangkan dan lebih mudah dipahami jika disampaikan menggunakan media augmented reality. Hal ini juga senada dengan hasil penelitian Perdana, dkk yang menyatakan bahwa, dari perhitungan kuesioner yang diberikan didapatkan bahwa sebesar $80 \%$ siswa menyatakan media pembelajaran AR membantu dalam memahami materi dan meningkatkan minat belajar. Artinya, dengan media ini pembelajaran menjadi menarik dan penuh dengan kreativitas. ${ }^{7}$ Pembelajaran yang menarik dan penuh kreatifitas dapat memudahkan siswa dalam memahami materi. $(\text { Sari, dkk })^{8}$

Penggunaan media ini tidak hanya berhasil meningkatkan jenjang kognitif di tingkat bawah saja, tetapi juga pada jenjang kognitif di tingkat atas. Artinya, tidak hanya siswa yang memiliki tingkat kecerdasan yang tinggi saja yang dapat memahami materi dengan menggunakan media pembelajaran berbasis Augmented Reality ini. $\mathrm{Hal}$ ini didukung oleh hasil angket siswa yang menolak pernyataan "penggunaan media Augmented Reality pada konsep dinamika partikel hanya dapat dipahami dengan tingkat kecerdasan yang tinggi”. Informasi ini menjelaskan bahwa penerapan media Augmented Reaity dapat diterima oleh siswa.

Dari hasil validasi oleh ahli media dan materi didapatkan informasi bahwa media ini baik isi pesan maupun cara menjelaskan pesan

\footnotetext{
${ }^{7}$ Mukhlis Yuzti Perdana, dkk., "Aplikasi Augmented Reality Pembelajaran Organ Pernapasan Manusia Pada Smartphone Android”, Jurnal Teknik Informatika, 2012, Vol 1, 2012, h. 1-11.

${ }^{8}$ Wellia Shinta Sari, dkk., "Multimedia Presentasi Pembelajaran Berbasis Augmented Reality untuk Pengenalan Panca Indra Dalam Mendukung Mata Pelajaran IPA Tingkat Sekolah Dasar”, Jurnal Semantik, 2012, h.105.
} 
sudah sesuai dengan karakteristik siswa. Apabila media pembelajaran yang digunakan telah sesuai dengan karakteristik siswa, maka hasil belajar siswa dapat meningkat. Hal ini senada dengan pendapat Burhanudin (dkk), yang menyatakan bahwa keberhasilan menggunakan media dalam proses pembelajaran untuk meningkatkan hasil belajar tergantung pada isi pesan, cara menjelaskan pesan, dan karakteristik penerima pesan.

Selain hal di atas, media pembelajaran ini juga dinilai unik dan kreatif. Hal ini dapat terlihat pada ketertarikan siswa saat melihat animasi yang dikemas dengan teknologi Augmented Reality ini. Pada awal pembelajaran, masih banyak siswa yang belum fokus, tetapi setelah media ini ditayangkan rasa ingin tahu siswa menjadi tinggi dan memperhatikan pembelajaran dengan baik. Media pembelajaran ini juga dapat membantu guru untuk menyampaikan materi, sehingga media ini dapat dikatakan praktis dan efisien. Hal ini senada dengan hasil penelitian Perdana, dkk yang menyatakan bahwa dari perhitungan kuesioner yang diberikan, didapatkan bahwa sebesar 96\% guru menyatakan media pembelajaran ini mempermudah dan membantu guru dalam menjelaskan pelajaran. Media ini dapat dikatakan praktis dan efisien karena media ini hanya menggunakan bantuan marker yang terbuat dari kertas dan sebuah laptop yang dilengkapi webcam. Dengan bantuan marker tersebut, alat peraga seperti katrol dan lift yang tidak mungkin di bawa ke dalam kelas dapat ditampilkan seolah-olah nyata berada di dalam kelas. $^{10}$

Dari hasil validasi ahli pada aspek desain visual, didapatkan skor 4 dan 5 pada semua indikator pada aspek tersebut. Artinya desain visual media ini berada pada kategori baik dan

${ }^{9}$ Elita Burhanuddin, dkk., Media. (Jakarta: Departemen Pendidikan Nasional Direktorat Jenderal Peningkatan Mutu Pendidik dan Tenaga Kependidikan, 2009), h.99.

${ }^{10}$ Mukhlis Yuzti Perdana, dkk., "Aplikasi Augmented Reality Pembelajaran Organ Pernapasan Manusia”. h. 1-11 sangat baik. Hal ini juga sesuai dengan hasil angket siswa pada indikator ketiga, yaitu tampilan animasi yang memperoleh nilai sebesar $84,86 \%$ atau berada pada kategori sangat baik. Pada indikator ini siswa menyatakan bahwa animasi menarik, tidak membosankan, dan keterangan-keterangan arah-arah gaya pada objek dapat membantu penjelasan materi.

Dengan desain visual yang menarik ini, pembelajaran menjadi tidak membosankan. Jika pembelajaran membosankan, maka siswa tidak akan bersemangat untuk belajar. Hal ini sesuai dengan pendapat Muhammad Abduh yang menyatakan banyak faktor yang menyebabkan ketidakmampuan siswa dalam menyerap pelajaran yang diberikan guru diantaranya bermula dari proses pembelajaran yang tidak menarik dan membosankan. Akibatnya siswa menjadi malas dan tidak tertarik terhadap materi yang disampaikan. ${ }^{11}$

Media Augmented Reality juga memberikan pengalaman baru bagi siswa dalam pembelajaran. Media ini tergolong media yang baru dalam dunia pembelajaran. Dengan media ini, siswa dapat secara langsung mengamati objek tiga dimensi dan melakukan pembelajaran yang lebih efektif dibandingkan dengan gambar satu atau dua dimensi. Selain itu media ini juga dapat memberikan derajat kebebasan sudut pandang, karena siswa dapat melihat animasi dari sisi kanan, kiri, depan, dan belakang. Objek tiga dimensi yang dihasilkan dari Augmented Reality dapat memotivasi dan memunculkan rasa ingin tahu siswa karena sistem pembelajaran Augmented Reality berbeda dengan pembelajaran yang sudah ada. $\mathrm{Hal}$ ini juga didukung oleh hasil angket siswa, yaitu sebesar $82,14 \%$ siswa menyatakan bahwa penerapan media Augmented Reality ini memberikan pengalaman baru yang menarik dan menginginkan media ini juga diterapkan pada materi lain pada konsep Fisika.

\footnotetext{
${ }^{11}$ Muhammad Abduh, Menciptakan Pembelajaran yang Menyenangkan, Artikel, 2012, h. 9.
} 
Media ini juga dapat memenuhi tuntutan kurikulum 2013. Pada kurikulum 2013 proses pembelajaran dituntut untuk menggunakan pendekatan scientific. Pendekatan scientific ini memiliki lima langkah pembelajaran, yaitu mengamati, menanya, eksplorasi, asosiasi, dan komunikasi. Untuk media pembelajaran berbasis Augmented Reality ini, sudah memenuhi dua langkah pembelajaran pada pendekatan scientific, yaitu pada langkah mengamati dan menanya. Hal ini sesuai dengan pendapat Sugiyono pada lembar validasi ahli materi. ${ }^{12}$ Sementara tiga langkah pembelajaran lain pada pendekatan scientific, yaitu eksplorasi, asosiasi, dan komunikasi dipenuhi saat proses pembelajaran berlangsung.

Dari beberapa kelebihan yang dikemukakan di atas, ada beberapa kekurangan media Augmented Reality ini. Kekurangan tersebut diantaranya tingkat interaktifitas masih kurang, tidak bisa melihat bagian bawah model tiga dimensi, kedalaman materi yang kurang, dan tidak dilengkapi audio. Selain itu perlu dibuat suatu alat untuk memposisikan marker yang digunakan, sehingga dapat mengurangi tingkat error pada program. Media ini juga lebih tepat digunakan pada materi-materi yang bersifat abstrak. Namun, secara keseluruhan penggunaan media Augmented Reality ini dapat berpengaruh pada hasil belajar siswa.

\section{Penutup}

Kesimpulan yang dapat diambil dari penelitian ini adalah media pembelajaran berbasis Augmented Reality berpengaruh terhadap hasil belajar Fisika siwa pada konsep dinamika partikel. Nilai rata-rata hasil belajar siswa lebih tinggi dibandingkan nilai rata-rata siswa yang belajar tanpa menggunakan media Augmented Reality. Selain itu kelas eksperimen unggul pada keempat jenjang kognitif (C1-C4).

\footnotetext{
${ }^{12}$ Sugiyono, Metode Penelitian Pendidikan (Pendekatan Kuantitatif, Kualitatif, dan R\&D), (Bandung: Alfabeta, 2008), cet. 5, h.75.
}

Berdasarkan angket tanggapan siswa, pembelajaran menggunakanmedia Augmented Reality berada pada kategori sangat baik.

Namun demikian, untuk memastikan pengaruh media pembelajaran berbasis Augmented Reality terhadap hasil belajar siswa, maka perlu dilakukan penelitian lebih lanjut seperti mencoba media ini di tempat dan subjek penelitian yang berbeda. Media Augmented Reality ini berada pada kategori sangat baik. Namun, untuk pengembangannya perlu dilakukan perbaikan seperti, menambahkan audio, untuk meningkatkan interaktivitas, dan mengemas media dalam bentuk ARbook.

\section{Daftar Pustaka}

Abduh, Muhammad, Menciptakan Pembelajaran yang Menyenangkan, Artikel, http://sumsel.kemenag.go.id/file/file/T ULISAN/jgri1331699416.pdf, (diakses Desember 2012).

Andriyadi, Anggi, Augmented Reality With ARToolkit. Bandar Lampung: ARTeam,2011.

Azuma, Ronald T.,A Survey of Augmented Reality., Hughes Research Laboratories: Malibu h.355-385, 1997., http://www.cs.unc.edu/ - azuma/ARpres ence.pdf, (diakses 10 Desember 2012).

Burhanuddin, Elita, dkk., Media, Jakarta: Departemen Pendidikan Nasional Direktorat Jenderal Peningkatan Mutu Pendidik dan Tenaga Kependidikan, 2009.

Martono, Kurniawan Teguh, “Augmented Reality Sebagai Metafora Baru dalam Teknologi Interaksi Manusia dan Komputer", Jurnal Sistem Komputer, vol.1, 2011, h. 60, http://jsiskom.undip.ac.id/index.php/js $\mathrm{k} /$ article/download/13/13, (diakses 10 Desember 2012).

Noor, Juliansyah, Metodologi Penelitian: Skripsi, Tesis, Disertasi, \& Karya Ilmiah, Jakarta: Kencana Prenada Media Group, 2012. 
Nugraha, Erwin, "Upaya Meningkatkan Hasil Belajar Siswa pada Materi Elektronika Dasar Menggunakan Media Pembelajaran Berbasis Augmented Reality", Skripsi pada Jurusan Teknik Elektro Fakultas Pendidikan Teknologi dan Kejuruan Universitas Pendidikan Indonesia, Bandung, 2013.

Perdana, Mukhlis Yuzti, dkk., "Aplikasi Augmented Reality Pembelajaran Organ Pernapasan Manusia Pada Smartphone Android", Jurnal Teknik Informatika, Vol 1, 2012, pp. 1-11, http://journal.pcr.ac.id/wp-content/upl oads/2012/09/Jurnal_mukhlis.pdf, (diakses 8 Desember 2012).
Sardiman,Interaksi dan Motivasi Belajar Mengajat, Jakarta: Rajawali Pers, 2011.

Sari, Wellia Shinta, dkk., "Multimedia Presentasi Pembelajaran Berbasis Augmented Reality untuk Pengenalan Panca Indra Dalam Mendukung Mata Pelajaran IPA Tingkat Sekolah Dasar", Jurnal Semantik, 2012, http://publikasi.dinus .ac.id/index.php/semantik/article/downl oad/62/28, (diakses 28 Desember 2012)

Sugiyono, Metode Penelitian Pendidikan (Pendekatan Kuantitatif, Kualitatif, dan R\&D), Bandung: Alfabeta, 2008.

Yudhawati, Ratna, dkk., Teori-Teori Dasar Psikologi Pendidikan, Jakarta: Prestasi Pustaka, 2011. 
72 | TARBIYA | Vol. I, No.1, Juni 2014 